\title{
Kajian Pemberdayaan Pelaku Usaha Mikro Kecil Dan Menengah (UMKM) Di Taman Jajanan Pasar Kota Gunungsitoli
}

\author{
Eliagus Telaumbanua \\ Sekolah Tinggi Ilmu Ekonomi Pembangunan Nasional \\ eliagus.tel@gmail.com
}

\begin{abstract}
Abstrak Usaha mikro kecil dan menengah (UMKM) dan mempunyai peran yang cukup penting dalam membangun perekonomian di Indonesia. UMKM merupakan kelompok usaha yang beroperasi di sektor informal dan padat karya sehingga dinilai mempunyai peran strategis sebagai sumber pencipta lapangan kerja. Tujuan yang hendak dicapai dalam penelitian ini adalah untuk mengetahui bagaimana implementasi pemberdayaan pelaku UMKM yang beroperasi disekitar taman jajanan pasar Kota Gunungsitoli, berdasarkan klasifikasi ukuran usaha yang tercantum dalam UU No. 20 Tahun 2008 tentang UMKM. Dan upaya pemerintah Kota Gunungsitoli dalam mengupayakan pemberdayaan berkesinambungan bagi para pelaku usaha. Jenis penelitian ini menggunakan metode deskriptif kualitatif. Dari hasil observasi potret situasi sosial yang dilakukan di lokasi taman jajan pasar kota Gunungsitoli secara deskriptif kualitatif penulis menjabarkan menyeluruh situasi sosial yang meliputi aspek tempat (place) yaitu taman jajanan berada dalam 1 lokasi, pelaku (actor) usaha mikro kecil dan menengah ada 64 orang dan aktivitas (activity) kegiatan usaha ada 6 kelompok, dilihat dari klasifikasi ukuran usaha bahwa pelaku usaha mikro ada 60 orang dan usaha kecil 4 orang sedangkan untuk ukuran usaha menengah tidak ditemukan pada lokasi objek penelitian ini. Berdasarkan hasil pengamatan penulis bahwa upaya pemerintah Kota Gunungsitoli melalui Disperindag dan instansi terkait dalam pemberdayaan berkesinambungan sudah cukup baik.
\end{abstract}

Kata Kunci Pemberdayaan, Pelaku Usaha dan Usaha Mikro Kecil Menengah

\section{PENDAHULUAN}

Usaha mikro kecil dan menengah (UMKM) dan mempunyai peran yang cukup penting dalam membangun perekonomian di Indonesia. Perekonomian di Indonesia secara nasional telah menunjukkan bahwa kegiatan Usaha Mikro, Kecil dan Menengah (UMKM) merupakan salah satu bidang usaha yang konsisten dan berkembang. Kebanyakan Usaha Mikro dan Kecil Menengah (UMKM) umumnya berbasis pada sumber daya ekonomi lokal dan tidak bergantung pada impor, serta hasilnya mampu untuk diekspor. Mengingat UMKM umumnya berbasis pada sumberdaya ekonomi lokal dan tidak bergantung pada impor, serta hasilnya mampu diekspor karena keunikannya, maka pembangunan UMKM diyakini akan memperkuat fondasi perekonomian nasional. Perekonomian Indonesia akan memiliki daya saing yang kuat jika UMKM telah menjadi pelaku utama yang produktif dan berdaya saing dalam perekonomian nasional. Untuk itu, pembangunan usaha mikro dan kecil perlu menjadi 
prioritas utama pembangunan ekonomi nasional dalam jangka panjang. Namun demikian perkembangan UMKM umumnya masih mengalami berbagai masalah dan belum sepenuhnya sesuai dengan yang diharapkan. Masalah yang hingga kini masih menjadi kendala dalam pengembangan usaha UMKM antara lain adalah keterbatasan modal yang dimiliki dan sulitnya UMKM mengakses sumber permodalan. Modal yang diperlukan untuk mengembangkan usaha mikro dan kecil lebih banyak mengandalkan modal pribadi dan perputaran hasil usaha yang diperoleh.

Kegiatan pemberdayaan pada sektor usaha mikro kecil dan menengah khususnya di Kota Gunungsitoli pasca pemekaran dari Kabupaten Nias sebelumnya ditinjau dari peristiwa bencana alam yang berdampak pada besarnya jumlah pelaku usaha mikro yang mengalami kerugian sebagai akibat dari banyaknya kehancuran tempat usaha yang pernah digeluti sebelumnya sebagai profesi atau rutinitas yang dilakukan dalam memenuhi kebutuhan hidup keluarga setiap harinya. Hal ini disebabkan karena belum adanya sistem jaminan sosial yang baik terutama sistem pemberi asuransi korban bencana alam khususnya bagi para pengusaha mikro kecil dan menengah, maka tidak sedikit dari mereka yang beralih profesi untuk mendapatkan kehidupan yang layak. Sehingga menjadi suatu keharusan bagi mereka yang menganggur untuk bekerja di sektor informal maupun membuka usaha sendiri di sektor informal. (Sari, 2013).

Menurut Habibi (2014), menambah modal bagi industri kecil bukan hal yang mudah. Bagi pengusaha kecil menengah meminjam uang di bank selain harus menanggung bunga yang cukup tinggi juga melalui prosedur yang tidak mudah. Selain itu tidak adanya jaminan anggunan merupakan alasan utama bagi sebagian besar UMKM untuk tidak mengajukan permohonan kredit kepada perbankan, tetapi lebih memilih pihak-pihak penyedia dana atau lembaga-lembaga non bank seperti rentenir. Dalam kondisi yang demikian, usaha mikro dan kecil menengah (UMKM) ini akan sangat sulit keluar dari permasalahan keterbatasan modal tersebut, kecuali bila ada intervensi dari pihak lain seperti pemerintah.

Menurut Hidayat dkk. (2011), Usaha Mikro Kecil Menengah (UMKM) merupakan kegiatan usaha yang mampu memperluas lapangan kerja, memberikan pelayanan ekonomi secara luas kepada masyarakat, berperan dalam proses pemerataan dan peningkatan pendapatan masyarakat, mendorong pertumbuhan ekonomi, dan berperan dalam mewujudkan stabilitas nasional.

\section{LANDASAN TEORI}

\section{A. Pemberdayaan Pelaku Usaha Mikro Kecil dan Menengah (UMKM)}

Secara etimologis, pemberdayaan berasal dari kata "daya" yang berarti kekuatan atau mengembangkan kemampuan. Pemberdayaan dapat diartikan sebagai suatu proses menuju berdaya, atau proses untuk memperoleh daya/kekuatan/kemampuan, atau proses pemberian daya/kekuatan/kemampuan dari pihak yang kurang atau belum berdaya. Daya artinya kekuatan, berdaya artinya memiliki kekuatan. Pemberdayaan artinya membuat sesuatu menjadi berdaya atau mempunyai daya atau mempunyai kekuatan. Pemberdayaan dalam bahasa Indonesia merupakan terjemahan dari empowerment dalam bahasa inggris. Secara konseptual pemberdayaan atau pemberkuasaan (empowerment), berasal dari kata 'power' (kekuasaan atau keberdayaan). Pemberdayaan sebagai sebuah proses perubahan kemudian memiliki konsep yang bermakna. Dengan kata lain, kemungkinan terjadinya proses pemberdayaan sangat tergantung pada dua hal, yaitu (pertama) bahwa kekuasaan dapat berubah. Jika kekuasaan tidak dapat berubah, pemberdayaan tidak mungkin terjadi dengan cara apapun. (Kedua) bahwa kekuasaan dapat diperluas. Konsep ini menekankan pada pengertian kekuasaan yang tidak statis, melainkan dinamis. Pemberdayaan menunjuk pada kemampuan orang, khususnya kelompok rentan dan lemah, sehingga 
mereka memiliki kekuatan atau kemampuan dalam (a) memenuhi kebutuhan dasarnya sehingga mereka memiliki kebebasan (freedom), dalam arti bukan saja bebas mengemukakan pendapat, melainkan bebas dari kelaparan, bebas dari kebodohan, bebas dari kesakitan; (b) menjangkau sumbersumber produktif yang memungkinkan mereka dapat meningkatkan pendapatannya dan memperoleh barang-barang dan jasa-jasa yang mereka perlukan; dan (c) berpartisipasi dalam proses pembangunan dan keputusan-keputusan yang mempengaruhi mereka. (Suharto, 2017:57)

Suryana, (2010), pemberdayaan mengandung dua arti pengertian yang pertama adalah to give power or authority, pengertian kedua to give ability to or enable. Pemaknaan pengertian yang pertama meliputi memberikan kekuasaan, mengalihkan kekuatan atau mendelegasikan otoritas kepada pihak yang kurang/belum berdaya. Di sisi lain pemaknaan pengertian kedua adalah memberikan kemampuan atau keberdayaan serta memberikan peluang kepada pihak lain untuk melakukan sesuatu.

Hafiluddin dkk (2014:71), Pemberdayaan diartikan sebagai upaya peningkatan profesionalisme dan kinerja pelaku pembangun di daerah, termasuk aparatur, organisasi sosial kemasyarakatan, Lembaga Swadaya Masyarakat (LSM), dunia usaha, dan anggota masyarakat untuk mengatasi berbagai masalah yang dihadapi serta merealisasikan aspirasi dan harapan masyarakat untuk mewujudkan peningkatan kualitas hidup kesejahteraan masyarakat. Terdapat ke-terkaitan yang sangat erat antara pemberdayaan masyarakat sebagai suatu strategi untuk mencapai sasaran pembangunan masyarakat di daerah dalam rangka mewujudkan keberhasilan pemerintah daerah.

Dengan demikian, pemberdayaan adalah sebuah proses dan tujuan. Pemberdayaan sebagai proses, pemberdayaan adalah serangkaian kegiatan untuk memperkuat kekuasaan atau keberdayaan kelompok lemah dalam masyarakat, termasuk individu-individu yang mengalami masalah kemiskinan. Sedangkan pemberdayaan sebagai tujuan, maka pemberdayaan menunjuk pada keadaan atau hasil yang ingin dicapai oleh sebuah perubahan sosial; yaitu masyarakat yang berdaya, memiliki kekuasaan atau mempunyai pengetahuan dan kemampuan dalam memenuhi kebutuhan hidupnya baik yang bersifat fisik, ekonomi, maupun sosial seperti memiliki kepercayaan diri, mampu menyampaikan aspirasi, mempunyai mata pencaharian, berpartisipasi dalam kegiatan sosial, dan mandiri dalam melaksanakan tugas-tugas kehidupannya. Pengertian pemberdayaan sebagai tujuan seringkali digunakan sehingga indikator keberhasilan pemberdayaan sebagai sebuah proses. (Suharto, 2017:59)

\section{B. Tujuan Pemberdayaan Pelaku Usaha Mikro Kecil dan Menengah (UMKM)}

Berdasarkan Undang-Undang RI Nomor 20 Tahun 2008 Pasal 5 tujuan pemberdayaan Usaha Mikro Kecil dan Menengah (UMKM) secara ekonomi adalah sebagai berikut: a. mewujudkan struktur perekonomian nasional yang seimbang, berkembang, dan berkeadilan; b. menumbuhkan dan mengembangkan kemampuan Usaha Mikro Kecil dan Menengah (UMKM) menjadi usaha yang tangguh dan mandiri; dan c. meningkatkan peran Usaha Mikro Kecil dan Menengah (UMKM) dalam pembangunan daerah, penciptaan lapangan kerja, pemerataan pendapatan, pertumbuhan ekonomi, dan pengentasan rakyat dari kemiskinan. Disisi lain Pemberdayaan pelaku usaha dapat meningkatkan pendapatan daerah hal ini berhubungan dengan retribusi yang dikenakan oleh pemerintah kepada pelaku usaha misalnya retribusi sampah maupun pengelolaan parkiran yang ada disetiap tempat-tempat usaha. Pendapatan daerah dan anggaran daerah merupakan unsur yang sangat penting dalam penyelenggaraan pemerintahan dan pembangunan daerah, oleh karena itu harus dikelola secara efektif dan efisien, mulai dari perencanaanya, pelaksanaan(implementasi) dan pengawasan. (Adisasmita, 2011)

\section{Prinsip Pemberdayaan Pelaku Usaha Mikro Kecil dan Menengah (UMKM)}

Ada tiga pendapat para ahli mengenai prinsip-prinsip pemberdayaan masing-masing 
diungkapkan secara terperinci. Rubin et.al (1992), ada lima prinsip pemberdayaan komunitas yaitu sebagai berikut

1. Pemberdayaan memerlukan break-even dalam setiap kegiatan yang dikelolanya, meskipun orientasinya berbeda dari organisasi bisnis, di mana dalam pemberdayaan komunitas, keuntungan yang diperoleh didistribusikan kembali dalam bentuk program atau kegiatan pembangunan lainnya.

2. Pemberdayaan selalu melibatkan partisipasi masyarakat baik dalam perencanaan maupun pelaksanaan yang dilakukan.

3. Dalam melaksanakan program pemberdayaan, kegiatan pelatihan merupakan unsur yang tidak bisa dipisahkan dari usaha pembangunan fisik

4. Dalam implementasinya, usaha pemberdayaan harus dapat memaksimalkan sumber daya, khususnya dalam hal pembiayaan baik yang berasal dari pemerintah, swasta maupun sumber-sumber lainnya

5. Kegiatan pemberdayaan harus dapat berfungsi sebagai penghubung antara kepentingan pemerintah yang bersifat makro dengan kepentingan masyarakat yang bersifat mikro.

Fitriyanti, (2014) mengemukakan bahwa pemberdayaan memiliki prinsip-prinsip sebagai berikut

1. Mengerjakan, artinya kegiatan pemberdayaan harus sebanyak mungkin melibatkan masyarakat untuk mengerjakan atau menerapkan sesuatu.

2. Akibat, artinya kegiatan pemberdayaan harus memberikan akibat atau pengaruh yang baik atau bermanfaat.

3. Asosiasi, artinya setiap kegiatan pemberdayaan harus dikaitkan dengan kegiatan lainnya.

Fitriyanti, (2014) mengungkapkan prinsip-prinsip pemberdayaan yang mencakup halhal sebagai berikut

1. Minat dan kebutuhan, pemberdayaan akan efektif jika mengacu pada minat dan kebutuhan masyarakat.

2. Organisasi masyarakat bawah, artinya pemberdayaan akan efektif jika mampu melibatkan/menyentuh organisasi masyarakat bawah, sejak dari setiap keluarga/kekerabatan, dan sebagainya.

3. Keragaman budaya, pemberdayaan harus memperhatikan adanya keragaman budaya.

4. Perubahan budaya, artinya setiap kegiatan pemberdayaan akan mengakibatkan perubahan budaya.

5. Kerja sama dan partisipasi, artinya pemberdayaan hanya akan efektif jika mampu menggerakkan partisipasi masyarakat untuk selalu bekerja sama dalam melaksanakan program-program pemberdayaan yang telah dirancang.

6. Demokrasi dalam penerapan ilmu, artinya dalam pemberdayaan harus selalu memberikan kesempatan kepada masyarakat untuk menawar setiap ilmu alternatif yang ingin diterapkan.

7. Belajar sambil bekerja, kegiatan pemberdayaan harus diupayakan agar masyarakat dapat belajar sambil bekerja atau belajar dari pengalaman tentang segala sesuatu yang mereka kerjakan.

8. Penggunaan metode yang sesuai, artinya pemberdayaan harus dilakukan dengan penerapan metode yang selalu disesuaikan dengan kondisi lingkungan sasarannya.

9. Kepemimpinan, artinya penyuluh tidak melakukan kegiatan-kegiatan yang hanya bertujuan untuk kepentingan/kepuasannya sendiri, dan harus mampu mengembangkan kepemimpinan.

10. Spesialis yang terlatih, artinya penyuluh/fasilitator harus benar-benar pribadi yang telah memperoleh latihan khusus tentang segala sesuatu yang sesuai dengan fungsinya sebagai 
penyuluh.

11. Segenap keluarga, artinya penyuluh/pemberdaya harus memperhatikan keluarga sebagai satu kesatuan dan unit sosial.

12. Kepuasan, artinya pemberdayaan harus mampu mewujudkan tercapainya kepuasan.

Menurut Fahrudin (2012:96-97), pemberdayaan adalah upaya untuk memampukan dan memandirikan masyarakat yang dilakukan dengan upaya sebagai berikut

1. Enabling, yaitu menciptakan suasana atau iklim yang memungkinkan potensi masyarakat berkembang. Titik tolaknya adalah pengenalan bahwa setiap manusia, setiap masyarakat memiliki potensi yang dapat dikembangkan. Pemberdayaan adalah upaya untuk membangun daya itu dengan cara mendorong (encourage), memotivasi dan membangkitkan kesadaran (awareness) akan potensi yang dimilikinya serta berupaya untuk mengembangkannya.

2. Empowering, yaitu meningkatkan kapasitas dengan memperkuat potensi atau daya yang dimiliki oleh masyarakat. Perkuatan ini meliputi langkah-langkah nyata seperti penyediaan berbagai masukan (input) serta pembukaan akses kepada berbagai peluang yang dapat membuat masyarakat menjadi makin berdayaan.

3. Protecting, yaitu melindungi kepentingan dengan mengembangkan sistem perlindungan bagi masyarakat yang menjadi subjek pengembangan. Dalam proses pemberdayaan harus dicegah yang lemah menjadi bertambah lemah, oleh karena kekurangberdayaan dalam menghadapi yang kuat. Melindungi dalam hal ini dilihat sebagai upaya untuk mencegah terjadinya persaingan yang tidak seimbang serta eksploitasi yang kuat atas yang lemah.

\section{Indikator Keberhasilan Pemberdayaan Pelaku UMKM}

Untuk mengetahui fokus dan tujuan pemberdayaan maka perlu diketahui berbagai indikator keberdayaan yang dapat menunjukan seseorang itu berdaya atau tidak. Schuler, Hashemi dan Riley yang dikutip oleh Edi Suharto (2017) mengembangkan delapan indikator pemberdayaan, yang mereka sebut sebagai empowerment index atau indeks pemberdayaan. Keberhasilan pemberdayaan masyarakat dapat dilihat dari keberdayaan mereka dalam kemampuan ekonomi, kemampuan mengakses manfaat kesejahteraan, dan kemampuan kultural dan politis. a. Kebebasan mobilitas, kemampuan individu untuk pergi keluar rumah atau wilayah tempat tinggalnya. Tingkat mobilitas ini dianggap tinggi jika individu mampu pergi sendirian. b. Kemampuan membeli komoditas kecil, kemampuan individu untuk membeli barang-barang pokok kebutuhan sehari-hari (beras, minyak, bumbu), kebutuhan dirinya (sabun, sampo, peralatan makeup). c. Kemampuan membeli komoditas besar, kemampuan individu untuk membeli barang sekunder atau tersier, seperti lemari pakaian, televisi, radio, koran, majalah dan lain sebagainya. d. Terlibat dalam keputusankeputusan rumah tangga, misalnya keputusan merenovasi rumah, membeli kambing untuk diternak. Membuat keputusankeputusan sendiri maupun secara musyawarah dilakukan secara kebersamaan dan kesetaraan dalam keluarga. e. Kebebasan relatif dari dominasi keluarga, tidak adanya diskriminasi dalam keluarga yang menimbulkan ketidakadilan dan pelarangan maupun kekerasan. f. Kesadaran hukum dan politik, keterlibatan individu dalam pengambilan peran dalam proses budaya, hukum dan politik. Misalnya mengetahui peran pemerintah desa atau kelurahan. g. Keterlibatan bersama untuk meningkatkan kesejahteraan publik, tindakan bersama untuk membela orang lain menghadapi perlakuan salah dalam keluarga dan masyarakat.

\section{E. Usaha Mikro Kecil Menengah (UMKM)}

Usaha Mikro, Kecil dan Menengah selalu menarik untuk dikaji, bukan hanya dari aspek 
ketahanan, aspek pembiayaan, perolehan pinjaman atau dari aspek manajerial usaha. Pada era globalisasi khususnya dengan adanya integrasi ekonomi di Asia Tenggara, yaitu penyatuan ekonomi (Economic Union) yang menjadikan Asia Tenggara menjadi suatu komunitas perekonomian dengan basis produksi tunggal membuat UMKM harus mampu mempertahankan eksistensinya ditengah gempuran ekonomi global.

UMKM adalah unit usaha produktif yang berdiri sendiri, yang dilakukan oleh orang perorangan atau Badan Usaha disemua sektor ekonomi (Tambunan, 2012:2). Pada prinsipnya, pembedaan antara Usaha Mikro (UMi), Usaha Kecil (UK), Usaha Menengah (UM) dan Usaha Besar (UB) umumnya didasarkan pada nilai asset awal (tidak termasuk tanah dan bangunan), omset rata-rata pertahun atau jumlah pekerja tetap. Namun definisi UMKM berdasarkan ketiga alat ukur ini berbeda disetiap Negara. Karena itu, memang sulit membandingkan pentingnya atau peran UMKM antar Negara. Tidak terdapat kesepakatan umum dalam membedakan sebuah Mikro Ekonomi (MiE) dari sebuah UK atau UK dari sebuah UM, dan yang terakhir dari sebuah UB. Namun demikian, secara umum, sebuah UMi mengerjakan lima atau kurang pekerja tetap, walaupun banyak usaha dari kategori ini tidak mengerjakan pekerja yang digaji, yang didalam literature sering disebut self employment. Sedangkan sebuah UKM dapat berkisar antara kurang dari 100 pekerja (Di Indonesia), dan 300 pekerja (Di China). Selain menggunakan jumlah pekerja, banyak Negara yang juga menggunakan nilai asset tetap (tidak termasuk gedung dan tanah) dan omset dalam mendefinisikan UMKM. Bahkan dibanyak Negara, definisi UMKM berbeda antar sektor, misalnya di Thailand, India, dan China, atau bahkan berbeda antar lembaga atau departemen pemerintah, misalnya Indonesia dan Pakistan (Tambunan, 2012:3).

Di Indonesia, definisi UMKM diatur berdasarkan Undang-Undang Republik Indonesia Nomor 20 Tahun 2008 tentang Usaha Mikro, Kecil, dan Menengah. Definisi menurut UU No. 20 Tahun 2008 tersebut adalah:

a. Usaha Mikro adalah usaha produktif milik orang perorangan dan/atau badan usaha perorangan yang memenuhi kriteria Usaha Mikro sebagaimana diatur dalam UndangUndang ini.

b. Usaha Kecil adalah usaha ekonomi produktif yang berdiri sendiri, yang dilakukan oleh orang perorangan atau badan usaha yang bukan merupakan anak perusahaan atau bukan cabang perusahaan yang dimiliki, dikuasai, atau menjadi bagian baik langsung maupun tidak langsung dari usaha menengah atau usaha besar yang memenuhi kriteria Usaha Kecil sebagaimana dimaksud dalam Undang-undang.

c. Usaha Menengah adalah usaha ekonomi produktif yang berdiri sendiri, yang dilakukan oleh orang perseorangan atau badan usaha yang bukan merupakan anak perusahaan atau cabang perusahaan yang dimiliki, dikuasai, atau menjadi bagian baik langsung maupun tidak langsung dengan Usaha Kecil atau usaha besar dengan jumlah kekayaan bersih atau hasil penjualan tahunan sebagaimana diatur dalam Undang-undang.

\section{Tabel 1}

Klasifikasi Usaha Mikro, Kecil dan Menengah berdasarkan UU No. 20 Tahun 2008 tentang UMKM

\begin{tabular}{|l|l|l|}
\hline \multicolumn{1}{|c|}{ Ukuran Usaha } & \multicolumn{1}{c|}{ Asset } & \multicolumn{1}{c|}{ Omset } \\
\hline Usaha Mikro & Minimal 50 Juta & Maksimal 300 Juta \\
\hline Usaha Kecil & >50 Juta - 500 Juta & Maksimal 3 Miliar \\
\hline Usaha Menengah & >500 Juta - 10 Miliar & >2,5 - 50 Miliar \\
\hline
\end{tabular}

Sumber: UU No. 20 Tahun 2008

Pada tabel ini di jelaskan bahwa ukuran usaha mikro memiliki asset minimal 50 juta dan 
omset maksimal 300 Juta, usaha kecil memiliki asset lebih 50 Juta sampai 500 Juta dan omset maksimal 3 Miliar sedangkan untuk usaha menengah lebih 500 Juta sampai 10 Miliar dan omsetnya lebih 2,5 sampai dengan 50 Miliar. Berbeda dengan BPS yang merumuskan kriteria UMKM berdasarkan jumlah tenaga kerja seperti yang terlihat pada Tabel di bawah ini

Tabel 2

Kriteria UMKM Berdasarkan Jumlah Tenaga Kerja

\begin{tabular}{|c|l|l|}
\hline No & \multicolumn{1}{|c|}{ Kelompok UMKM } & \multicolumn{1}{c|}{ Jumlah Tenaga Kerja } \\
\hline 1 & Usaha Mikro & Kurang dari 4 orang \\
\hline 2 & Usaha Kecil & $5-19$ orang \\
\hline 3 & Usaha Menengah & 20 sampai dengan 99 orang \\
\hline
\end{tabular}

Sumber : Badan Pusat Statistik 2006

Pada tabel ini dijelaskan bahwa Kelompok UMKM berdasarkan Jumlah Tenaga Kerja Usaha mikro Kurang dari 4 orang, Usaha kecil 5 sampai dengan 19 orang dan Usaha menengah 20 sampai dengan 99 orang.

Data pada sensus BPS 2016 Pelaku usaha 2016 berjumlah 8.722 usaha, sebelum tahun 2006 berjumlah 7.620 usaha maka terjadi peningkatan sebesar 14,46 persen. Dengan rincian sebagai berikut

Tabel 3

Pelaku Usaha Se-Kota Gunungsitoli

\begin{tabular}{|c|l|r|}
\hline No & Kecamatan & Pelaku Usaha/Usaha \\
\hline 1 & Gunungsitoli & 5.821 \\
\hline 2 & Gunungsitoli Selatan & 612 \\
\hline 3 & Gunungsitoli Utara & 844 \\
\hline 4 & Gunungsitoli Barat & 240 \\
\hline 5 & Gunungsitoli Idanoi & 914 \\
\hline 6 & Gunungsitoli Alo'oa & 291 \\
\hline \multicolumn{2}{|c|}{ Jumlah Usaha } & 8.722 \\
\hline
\end{tabular}

Sumber : Data BPS 2016

Tabel diatas memperlihatkan bahwa pelaku usaha di Kota Gunungsitoli dengan 6 kecamatan yaitu Kecamatan Gunungsitoli berjumlah 5.821 pelaku usaha, Kecamatan Gunungsitoli Selatan 612 pelaku usaha, Kecamatan Gunungsitoli Utara 844 pelaku usaha, Kecamatan Gunungsitoli Barat 240 pelaku usaha, Kecamatan Gunungsitoli Idanoi 914 dan Kecamatan Gunungsitoli Alo'oa 291 pelaku usaha sehingga total jumlah pelaku usaha di Kota Gunungsitoli 8.722. Data ini merupakan data BPS pada tahun 2016 dimana data sensus yang dilakukan setiap 10 tahun sekali maka untuk selanjutnya akan dilakukan pada tahun 2026.

\section{F. Pelaku Usaha}

Dalam Undang-undang Nomor 8 Tahun 1999 Tentang Perlindungan Konsumen Pasal 1 angka 3 menyebutkan bahwa pelaku usaha adalah setiap orang-perorang atau badan usaha, baik yang berbentuk badan hukum maupun bukan badan hukum yang didirikan dan berkedudukan atau melakukan kegiatan dalam wilayah hukum negara Republik Indonesia, baik sendiri maupun bersama melalui perjanjian menyelenggarakan kegiatan usaha dalam berbagai bidang ekonomi. Dalam penjelasannya menyatakan bahwa pelaku usaha yang 
termaksud dalam pengertian ini adalah perusahaan, koperasi, BUMN, korporasi, importer, pedagang, distributor, dan lain-lain.

Dalam defenisi pelaku usaha yang dimaksudkan dalam Undang-undang Nomor 8 Tahun 1999 Tentang Perlindungan Konsumen Pasal 1 angka 3 sama dengan cakupan yang diklaim oleh negara-negara eropa khususnya belanda, karena pelaku usaha dapat berupa badan hukum atau orang perorang. Dalam Pasal 3 Directive Product Liability Directive (selanjutnya disebut Directive) sebagai pedoman bagi negara Masyarakat Ekonomi Eropa (MEE) Mendefenisikan Pelaku usaha/produsen adalah

1. Produsen berarti pembuat produk akhir, produsen dari setiap bahan mentah, atau pembuat dari suatu suku cadang dan setiap orang yang memasang nama, merek atau suatu tanda pembedaan yang lain pada peroduk, mejadikan dirinya sebagai produsen.

2. Tanpa mengurangi tanggung gugat produsen, maka setiap orang yang mengimpor suatu produk untuk dijual, dipersewakan, atau untuk leasing, atau setiap bentuk pengedaran dalam usaha perdagangannya dalam Masyarakat Eropa, akan dipandang dalam arti produsen dalam arti Directive ini, dan akan bertanggung gugat sebagai produsen.

3. Dalam hal suatu produsen tidak dikenal identitasnya, maka setiap leveransir/supplier akan bertanggung gugat sebagai produsen, kecuali ia memberitahukan orang yang menderita kerugian dalam waktu yang tidak terlalu lama mengenai identitas produsen atau orang yang menyerahkan produk itu kepadanya. Hal yang sama akan berlaku dalam kasus barang/produk yang diimpor, jika produk yang bersangkutan tidak menunjukan identitas importir sebagaimana dimaksud dalam ayat 2, sekalipun nama produsen dicantumkan.

Bentuk dan wujud pelaku usaha dapat kita ketahui dengan usaha perorangan maupun badan usaha dan kategorinya sebagai berikut

1. Orang perorangan, yakni setiap individu yang melakukan kegiatan usahanya secara seorang diri;

2. Badan usaha, yakni kumpulan individu yang secara bersama-sama melakukan kegiatan usaha. Badan usaha selanjutnya dapat dikelompokkan kedalam dua kategori, yakni :

a. Badan hukum. Menurut hukum, badan usaha yang dapat dikelompokkan ke dalam kategori badan hukum adalah yayasan, perseroan terbatas dan koperasi.

b. Bukan badan hukum. Jenis badan usaha selain ketiga bentuk badan usaha diatas dapat dikategorikan sebagai badan usahan bukan badan hukum, seperti firma, atau sekelompok orang yang melakukan kegiatan usaha secara insidentil.

Badan usaha tersebut harus memenuhi salah satu kriteria ini:

1. Didirikan dan berkedudukan di wilayah hukum Negara Republik Indonesia.

2. Melakukan kegiatan di wilayah hukum Negara Republik Indonesia.

Dengan demikian jelaslah bahwa pengertian pelaku usaha menurut UU PK sangat luas. Yang dimaksud dengan pelaku usaha bukan hanya produsen, melainkan hingga pihak terakhir yang menjadi perantara antara produsen dan konsumen, seperti agen, distributor dan pengecer (konsumen perantara).

Pada dasarnya, terdapat tiga jenis pelaku bisnis dan karakterisitiknya :

1. Pedagang: orang yang melakukan usaha. Karakteristiknya yaitu

a. Bidang usahanya biasanya tunggal, atau hanya satu.

b. Tidak memiliki pegawai atau karyawan.

c. Minim inovasi dan pengembangan usaha.

d. Hanya menjalankan rutinitas usaha.

e. Pendapatan hanya dari satu sumber, sehingga apabila sedang lesu, penghasilan berkurang.

2. Pebisnis atau pengusaha: orang yang melakukan bisnis. Karakteristiknya yaitu 
a. Sudah memiliki karyawan atau staf.

b. Sudah memiliki struktur dan sistem bisnis.

c. Memiliki sejumlah usaha.

d. Hanya fokus di pengembangan usaha.

e. Masih minim inovasi dan kreativitas.

f. Pendapatan tidak hanya dari satu sumber sehingga sudah bisa saling menutupi.

g. Meski ada sedikit usaha pengembangan, pengusaha masih menjalani rutinitas usaha dengan penghasilan tetap.

h. Bila dibiarkan terus usahanya tanpa inovasi, lama kelamaan akan hancur tergerus perkembangan zaman.

3. Entrepreneur: orang yang melakukan wirausaha. Karakterisitiknya yaitu

a. Sudah memiliki karyawan atau staf.

b. Sudah menjalankan bisnis secara sistematis dan terstruktur.

c. Memiliki sejumlah usaha.

d. Memiliki nafsu dan mabuk mengembangkan usaha.

e. Berambisi memperluas bisnis.

f. Memiliki inovasi dan kreativitas dalam usahanya.

g. Pandai mengambil peluang usaha.

h. Pendapatan bisa dari berbagai sumber usahanya.

i. Rajin mencari terobosan-terobosan baru.

\section{METODOLOGI PENELITIAN}

Penelitian ini dilakukan di lokasi taman jajanan atau sekitar ex pelabuhan lama pasar kota Gunungsitoli dengan menggunakan jenis penelitian deskriptif kualitatif. Metode penelitian kualitatif dapat diartikan sebagai metode yang berlandaskan pada filsafat postpositivisme/entrepretif digunakan pada kondisi obyek yang alamiah dimana peneliti sebagai instrument kunci, teknik pengumpulan data dilakukan secara trianggulasi (gabungan), analisis data bersifat induktif/kualitatif, dan hasil penelitian kualitatif lebih menekankan makna dari pada generalisasi. Dalam pandangan penelitian kualitatif bersifat holistik sehingga peneliti tidak menetapkan penelitiannya hanya berdasarkan variable penelitian, tetapi keseluruhan situasi sosial yang meliputi aspek tempat (place), pelaku (actor) dan aktivitas (activity) yang berinteraksi secara sinergis. (Sugiyono, 2016:347)

Instrumen dan teknik pengumpulan data dengan cara observasi, wawancara, dokumentasi dan juga tinjauan pustaka dari 64 orang pelaku usaha yang berada dikawasan taman jajanan pasar Kota Gunungsitoli menjadi populasi dan sampelnya dilakukan dengan cara Nonprobalitity Sampling yaitu teknik pengambilan sampel yang tidak memberikan peluang atau kesempatan sama bagi setiap unsur atau anggota populasi untuk dipilih menjadi sampel secara spesifik sampling incidental teknik penentuan sampel berdasarkan kebetulan, yaitu siapa saja yang secara kebetulan insidental bertemu dengan peneliti dapat digunakan sebagai sampel, bila dipandang orang yang kebetulan ditemui cocok sebagai sumber data. (Sugiyono, 2016:154). Proses yang dilakukan dapat dilihat pada gambar berikut 
Tabel 2. Tahap Observasi

\begin{tabular}{|c|c|c|}
\hline 1 & 2 & 3 \\
\hline $\begin{array}{l}\text { Tahap Deskripsi, } \\
\text { Memasuki situasi sosial } \\
\text { ada tempat, aktor dan } \\
\text { aktivitas }\end{array}$ & $\begin{array}{l}\text { Tahap Reduksi, } \\
\text { Menentukan Fokus } \\
\text { memilih diantara yang } \\
\text { telah dideskripsikan }\end{array}$ & $\begin{array}{l}\text { Tahap Seleksi, } \\
\text { Mengurai fokus } \\
\text { menjadi komponen } \\
\text { yang lebih rinci }\end{array}$ \\
\hline Kesimpulan & Kesimpulan & Kesimpulan \\
\hline 1 & 2 & 3 \\
\hline
\end{tabular}

Sumber : Sugiyono, 2016:283

\section{HASIL PENELITIAN}

\section{A. Hasil Observasi}

Observasi yang dilakukan penulis berdasarkan hasil pengamatan langsung dan pencatatan mengacu pada kajian pustaka diperoleh hasil sebagai berikut

1. Klasifikasi Pelaku Usaha

\section{Tabel 4}

Hasil Observasi Lapangan

Klasifikasi Pelaku Usaha Berdasarkan UU No. 20 Tahun 2008 di Taman Jajanan Pasar Kota Gunungsitoli

\begin{tabular}{|c|c|c|c|c|c|c|}
\hline \multirow[t]{2}{*}{ No } & \multirow{2}{*}{$\begin{array}{l}\text { Kegiatan Usaha } \\
\text { (aktifitas) }\end{array}$} & \multirow{2}{*}{$\begin{array}{l}\text { Pelaku } \\
\text { Usaha }\end{array}$} & \multirow{2}{*}{$\begin{array}{l}\text { Alat } \\
\text { Usaha } \\
\text { (Unit) }\end{array}$} & \multicolumn{2}{|c|}{ Sumber Alat Usaha } & \multirow{2}{*}{$\begin{array}{l}\text { Ukuran } \\
\text { Usaha }\end{array}$} \\
\hline & & & & $\begin{array}{l}\text { Sumbangan } \\
\text { Pemerintah }\end{array}$ & $\begin{array}{l}\text { Mandiri/Milik } \\
\text { Sendiri }\end{array}$ & \\
\hline 1 & $\begin{array}{l}\text { Pedagang kelapa } \\
\text { muda }\end{array}$ & $\begin{array}{r}32 \\
\text { orang } \\
\end{array}$ & $\begin{array}{r}32 \text { unit } \\
\text { gerobak }\end{array}$ & 30 unit & 2 unit & Mikro \\
\hline 2 & $\begin{array}{l}\text { Pedagang } \\
\text { sate/nasi goreng }\end{array}$ & $\begin{array}{r}12 \\
\text { orang }\end{array}$ & $\begin{array}{l}12 \text { unit } \\
\text { gerobak }\end{array}$ & - & 12 unit & Mikro \\
\hline 3 & $\begin{array}{l}\text { Pedagang } \\
\text { martabak }\end{array}$ & 4 orang & $\begin{array}{l}4 \text { unit } \\
\text { mobil }\end{array}$ & - & 4 unit & Kecil \\
\hline 4 & Pedagang jamu & 1 orang & $\begin{array}{r}1 \text { unit } \\
\text { sepeda } \\
\text { motor }\end{array}$ & - & 1 unit & Mikro \\
\hline 5 & $\begin{array}{l}\text { Pedagang es } \\
\text { boba/ martabak } \\
\text { telur }\end{array}$ & $\begin{array}{r}12 \\
\text { orang }\end{array}$ & $\begin{array}{l}12 \text { unit } \\
\text { gerobak }\end{array}$ & - & 12 unit & Mikro \\
\hline 6 & $\begin{array}{l}\text { Pedagang } \\
\text { batagor/siomay }\end{array}$ & 3 orang & $\begin{array}{l}3 \text { unit } \\
\text { gerobak }\end{array}$ & - & 3 unit & Mikro \\
\hline
\end{tabular}

Sumber : Data Primer Penulis

Pada tabel 3 diatas ukuran usaha dapat diklasifikasikan bahwa pelaku usaha mikro ada 64 orang terdiri dari pedagang kelapa muda 32 orang, pedagang sate/nasi goreng 12 orang, pedagang martabak 4 orang, pedagang jamu 1 orang, pedagang es boba/martabak telur 12 orang dan pedagang batagor/siomay 3 orang. Alat usaha yang digunakan pelaku usaha dalam melakuakn aktifitasnya yaitu pedagang kelapa muda 32 unit gerobak dimana 30 unit bantuan dari pemerintah Kota Gunungsitoli dan 2 unit milik sendiri. Pedagang sate/ nasi goreng 12 
unit gerobak milik sendiri, pedagang martabak dengan 4 unit mobil milik sendiri biasanya ini dikenal dengan istilah truck food atau pick up food yaitu berjualan makanan dengan menggunakan kendaraan roda empat, pedagang jamu 1 unit gerobak dan sepeda motor, pedagang es boba/martbak telur 12 unit gerobak dan pedagang batagor/siomay 3 unit gerobak. Berdasarkan asset yang dimiliki minimal bahkan kurang dari 50 juta rupiah dan usaha kecil ada 4 (empat) orang hal ini dikarenakan modal usaha yang digunakan adalah mobil sebagai alat usaha jualan dan assetnya diatas 50 juta rupiah. Sedangkan ukuran usaha dengan klasifikasi menengah tidak berada atau tidak ditemukan dalam objek lokasi penelitian ini.

2. Kriteria UMKM berdasarkan jumlah tenaga kerja

Tabel 5

Hasil Observasi Lapangan

Kriteria UMKM Berdasarkan Jumlah Tenaga Kerja di Taman Jajanan Pasar Kota Gunungsitoli

\begin{tabular}{|c|c|c|c|c|c|c|}
\hline \multirow[t]{2}{*}{ No } & \multirow{2}{*}{$\begin{array}{l}\text { Kegiatan Usaha } \\
\text { (aktifitas) }\end{array}$} & \multirow{2}{*}{$\begin{array}{l}\text { Pelaku } \\
\text { Usaha }\end{array}$} & \multirow{2}{*}{$\begin{array}{l}\text { Tenaga } \\
\text { Kerja } \\
\text { (Orang) }\end{array}$} & \multicolumn{2}{|c|}{ Sifat Tempat Usaha } & \multirow{2}{*}{$\begin{array}{l}\text { Kriteric } \\
\text { Usaha }\end{array}$} \\
\hline & & & & Permanen & $\begin{array}{c}\text { Tidak } \\
\text { Permanen }\end{array}$ & \\
\hline 1 & $\begin{array}{l}\text { Pedagang kelapa } \\
\text { muda }\end{array}$ & 32 orang & $<4$ Orang & 32 & - & Mikro \\
\hline 2 & $\begin{array}{l}\text { Pedagang } \\
\text { sate/nasi goreng }\end{array}$ & 12 orang & $<4$ Orang & - & 12 & Mikro \\
\hline 3 & $\begin{array}{l}\text { Pedagang } \\
\text { martabak }\end{array}$ & 4 orang & $<4$ Orang & - & 4 & Kecil \\
\hline 4 & Pedagang jamu & 1 orang & $<4$ Orang & - & 1 & Mikro \\
\hline 5 & $\begin{array}{l}\text { Pedagang es } \\
\text { boba/ martabak } \\
\text { telur }\end{array}$ & 12 orang & $<4$ Orang & - & 12 & Mikro \\
\hline 6 & $\begin{array}{l}\text { Pedagang } \\
\text { batagor/siomay }\end{array}$ & 3 orang & $<4$ Orang & - & 3 & Mikro \\
\hline
\end{tabular}

Pada tabel 5 diatas kriteria usaha dilihat dari 64 orang pelaku berdasarkan jumlah tenaga kerjanya pada masing-masing kegiatan usaha, (1) pedagang kelapa muda 32 usaha, tenaga kerja kurang dari 4 orang sifat tempat usaha permanen atau dengan kata lain gerobak yang digunakan untuk berjualan tidak berpindah-pindah tetap dilokasi yang telah ditetapkan pemerintah kriterianya usaha mikro, (2) pedagang sate/nasi goreng 12 usaha, tenaga kerja ada sampai 4 orang tidak lebih, sifat tempat usaha tidak permanan dengan perkataan lain gerobak yang digunakan gerobak sorong yang berada ditempatnya yang sudah ditentukan pada saat jualan dan selesai jualan dibawa kembali oleh pedagang kriterinya usaha mikro, (3) pedagang martabak 4 usaha, tenaga kerjanya kurang dari 4 orang, sifat tempat usaha tidak permanen karena menggunakan kendaraan roda empat (truck food/pick up food) dan kriteria usahanya mikro. (4) pedagang jamu 1 usaha,tenaga kerja kurang dari 4 orang dan sifat tempat usaha tidak permananen karena gerobak yang digunakan menggunakan kendaraaan roda 2 kriteria usaha mikro. (5) pedagang es boba/martabak telur 12 usaha, tenaga kerjanya ada tapi kurang dari 4 orang, tempat usaha tidak permanaen karena gerobak yang digunakan hanya beroperasi pada saat berjualan. dan (6) pedagang batagor/siomay 3 usaha, tenaga kerja yang ada kurang 
dari 4 orang dan tempat usaha juga tidak permananen. Berdasarkan kriteria usaha yang dari Badan Pusat Statistik (2006), maka kriteria usaha khususnya yang berada di taman jajanan pasar Kota Gunungsitoli semua adalah usaha mikro.

\section{B. Hasil wawancara dan tinjauan pustaka}

Hasil pengamatan penulis bila ditinjau dari spesifikasi ukuran usaha berdasarkan Undang-Undang No. 20 Tahun 2008 tentang UMKM bahwa asset yang harus dimiliki minimal 50 Juta dan omset maksimal 300 Juta para pedagang ataupun pelaku usaha di taman jajajan pasara Kota Gunungsitoli tidak mencapai asset maupun omset sehingga perlu pengkajian dalam mengkategorikan dan mengklasifikasikan para pelaku usaha. Hal ini sangat penting dalam memenuhi persyaratan dalam memberdayakan para pelaku usaha khususnya untuk mendapatkan bantuan modal baik dari pemerintah maupun pihak swasta.

Dalam melakukan pemberdayaan berkesinambungan dilakukan melalui bantuan pemerintah, Kadis Perdagangan dan Perindustrian Kota Gunungsitoli, Yurisman (Rabu, 3/9/2020).

"Pihaknya telah melakukan pendataan terhadap para pelaku UMKM di kota Gunungsitoli. Pengumpulan data itu bertujuan untuk penyaluran bantuan produktif sebesar 2,4 Juta terhadap pelaku UMKM di Kota Gunungsitoli yang terdampak pandemi Covid-19. Sesuai Peraturan Menteri Koperasi dan UMKM Nomor 6 Tahun 2020 Pedoman Umum Penyaluran Bantuan Pemerintah bagi Pelaku Usaha Mikro untuk Mendukung Pemulihan Ekonomi Nasional dalam Rangka Menghadapi Ancaman yang Membahayakan Perekonomian Nasional Serta Penyelamatan Ekonomi Nasional pada Masa Pandemi Corona Virus Disease 2019 (Covid19), adapun yang menjadi kriteria penerima bantuan dibagi menjadi lima yakni

1. Berkewarganegaraan Indonesia (WNI).

2. Mempunyai Nomor Induk Kependudukan (NIK).

3. Mempunyai Usaha Mikro Kecil Menengah (UMKM) bermodalkan 50 Juta ke Bawah.

4. Bukan ASN/PNS

5. Tidak sedang mempunyai tunggakan/kredit di Bank, seperti KUR.

Selanjutnya setelah mengumpulkan data pelaku UMKM, data dikirimkan ke Kementerian Koperasi dan UMKM. Sedangkan untuk validasi dan verifikasi dilakukan OJK bersama BPKP",setelah tahap validasi dan verifikasi dilakukan maka proses selanjutnya adalah penyaluran dilaksanakan oleh perbankan yang ditunjuk pemerintah pusat. "Dinas Perdagangan dan Perindustrian Kota Gunungsitoli hanya mengumpulkan data. Untuk penyaluran bantuan, dilakukan melalui nomor rekening masing-masing pelaku UMKM".

Demikian halnya dengan dana bergulir yang diperuntukan untuk memberdayakan pelaku usaha, Kepala UPTD Dana Bergulir kota Gunungsitoli Deskariawan. "Mengawali tahun 2021, UPTD Dana Bergulir kota Gunungsitoli sudah gelontorkan sebesar 335 juta rupiah kepada pelaku usaha mikro di kota Gunungsitoli. Sejak capaian tahun 2020, dari 3 milyar rupiah dana yang diinvestasikan oleh Pemerintah Kota Gunungsitoli ke UPTD, dana bergulir Kota Gunungsitoli, sudah dicairkan 2 milyar 907 juta rupiah kepada para pelaku usaha mikro penerima dana bergulir," Untuk tahun 2021, Pemerintah kota menginvestasikan 1 milyar rupiah yang diperuntukkan buat pengelolaan dana bergulir bagi para pelaku usaha mikro di wilayah kota Gunungsitoli, dan diawal tahun 2021, pihaknya telah mencairkan dana tersebut kepada 16 pelaku usaha mikro. Jadi, untuk tahun 2020, pencairan dana bergulir ini sudah sampai tahap 12, maka di awal tahun 2021 ini tahap ke 13. Dalam kurun waktu terakhir, antusias masyarakat cukup tinggi untuk mengajukan permohonan dana bergulir. Deskariawan menilai hal tersebut sebagai dampak sosialisasi ke masyarakat terkait pelayanan dana bergulir yang difasilitasi oleh pemerintah kota Gunungsitoli. Dari semua 
pelaku usaha mikro penerima dana bergulir tersebut antara lain penjual sembako, peternak dan sebagainya. "Sebagian besar debitur, rata-rata pinjaman dana bergulir mereka sebesar 25 juta rupiah. Sejauh ini patut disyukuri pembayaran cicilan untuk pembayaran dana bergulir dari para debitur lancar dan tak terkendala." (Selasa, 02/03/2021)

Disisi lain penulis memperoleh informasi bahwa masih ada pelaku usaha mikro yang belum mendapatkan informasi tentang pemberdayaan pelaku usaha melalui bantuan produktif maupun dana bergulir ini. Ina Joel Laoli, penjual kelapa muda (Sabtu, 24/04/2021) "saya belum mendapatkan informasi tentang bantuan pemerintah baik bantuan produktif maupun dana bergulir. Gerobak ini saya buat dari modal sendiri bersama suami saya untuk menjual kelapa muda. Kelapa muda yang sebelum pandemi covid 19 harganya hanya Rp. 5.000,/buah dimasa pandemi naik menjadi Rp. 6.000,- dan Rp. 7.000,-/buah dan sekarang harganya Rp. 8.000,-/buah tergantung harga dari pemasoknya, sekarang ini dari pemasok kami beli Rp.5000,-/buah. Dan setiap bulan kami membayar retribusi sampah sebesar Rp. 10.000,bulan."

Berdasarkan penjelasan di atas maka hal ini sesuai referensi penelitian menurut Rubin et.al (1992) tentang prinsip-prinsip pemberdayaan menyatakan pada poin 4 bahwa dalam implementasinya, usaha pemberdayaan harus dapat memaksimalkan sumber daya, khususnya dalam hal pembiayaan baik yang berasal dari pemerintah, swasta maupun sumber-sumber lainnya dan pada poin 5 dinyatakan bahwa kegiatan pemberdayaan harus dapat berfungsi sebagai penghubung antara kepentingan pemerintah yang bersifat makro dengan kepentingan masyarakat yang bersifat mikro. Dan hal tersebut telah dilakukan oleh Pemerintah Kota Gunungsitoli melalui Dinas Perindustrian dan Perdagangan berupa bantuan pengadaan gerobak bagi penjual kelapa muda dan juga memfasilitasi pelaku usaha untuk mendapatkan bantuan produktif dan dana bergulir. Kenyataannya klasifikasi Usaha Mikro, Kecil dan Menengah berdasarkan UU No. 20 Tahun 2008 tentang UMKM ukuran usahanya tidak memenuhi standar dilihat dari asset dan omset para pelaku usahanya karena rata-rata masih dibawah Rp.50.000.000,- namun hal ini di antisipasi dengan adanya Peraturan Menteri Koperasi dan UMKM Nomor 6 Tahun 2020 yang menjadi syarat penerima bantuan pelaku UMKM pada poin 3 yaitu mempunyai Usaha Mikro Kecil Menengah (UMKM) bermodalkan 50 Juta ke bawah bukan lagi minimal 50 Juta.

\section{KESIMPULAN}

Berdasarkan hasil penelitian yang penulis lakukan, para pelaku usaha mikro, kecil dan menengah yang berada di lokasi taman jajanan pasar kota Gunungsitoli dapat dikembangkan melalui pemberdayaan sumberdaya modal. Upaya pemerintah Kota Gunungsitoli melalui Dinas Perdagangan dan Perindustrian dalam pengembangan UMKM sudah sangat baik, khususnya dalam memberikan bantuan modal kepada pelaku usaha yang bermanfaat dalam mengembangkan usahanya. Namun perlu juga dilakukan monitoring dan evaluasi kepada para pelaku usaha apakah benar-benar mengeluti profesinya sebagai pelaku UMKM atau hanya sekedar untuk memenuhi persyaratan untuk memperoleh bantuan seperti bantuan fisik pengadaan gerobak atau bantuan lainnya seperti bantuan dana produktif dan dana bergulir dari pemerintah. Dan kontrol pendataan para pelaku usaha juga sangat penting dilakukan oleh pihak yang berwenang sesuai ukuran usaha yang berlaku dalam Undang-Undang dan regulasinya, hal ini untuk menghindari penggelembungan data para pelaku usaha yang fiktif. Sehingga penyaluran bantuan baik dari pemerintah maupun sumber-sumber lainnya tepat sasaran dan bermanfaat bagi pelaku usaha dalam mengembangkan usahanya dengan daya kreatifitas dan daya inovasi untuk menjadikan Kota Gunungsitoli berdaya saing, nyaman dan 
sejahtera. Feedback bagi pemerintah selain parkiran yang tertata rapi maka perlu juga pembangunan toilet umum di beberapa titik lokasi taman jajanan agar pengunjung merasa nyaman dan tidak membuang air kecil/besar dengan sembarangan di pinggir pantai. Dengan demikian tercipta kebersihan lingkungan yang layak.

\section{DAFTAR PUSTAKA}

Adisasmita, Raharjo. 2011. Pengelolaan pendapatan dan anggaran daerah. Graha Ilmu. Yogyakarta

Badan Pusat Statistik Jakarta Pusat, 2006. Pendataan Sosial Ekonomi Tahun 2005. Jakarta Pusat : Badan Pusat Statistik

Badan Pusat Statistik Kota Gunungsitoli , 2016. Kota Gunungsitoli Dalam Angka (Gunungsitoli Municipality In Figures). Gunungsitoli, Badan Pusat Statistik Kota Gunungsitoli.

Fahrudin, Adi. (2012). Pengantar Kesejahteraan Sosial. Bandung: Refika. Aditama.

Habibi, Indra Resqi. 2014. Analisis Dampak Pemberian Kredit Lembaga Keuangan Terhadap Usaha Mikro Kecil dan Menengah Di Kota Tarakan. Skripsi. Fakultas Borneo Tarakan.

Hafiluddin Moch. Rochjadi 1, Suryadi1.2, Choirul Saleh1.2Strategi Pemberdayaan Usaha Mikro Kecil dan Menengah (UMKM) Berbasis "Community Based Economic Development" (Studi pada pelaku UMKM di Kecamatan Sukodono Kabupaten Sidoarjo) Jurnal Wacana- Vol. 17, No. 2 (2014)

Hidayat, Iman Pirman dan Adi Ridwan Fadillah, Pengaruh Penyaluran Kredit Usaha Mikro Kecil Menengah (UMKM) Dan Pendapatan Operasional Terhadap Laba Operasional (Kasus Pada PT.Bank Jabar Banten Tbk), Jurnal Dipublikasikan Pada Digital Library Fakultas Ekonomi Jurusan Akuntansi Universitas Siliwangi, http://imanph.files.wordpress.com/2011/10/imanumkm-bjb.pdf Kasmir, Manajemen Perbank

Fitriyanti Hanifa, (2014), "Strategi Pengembangan Desa Wisata Talun Melalui Model Pemberdayaan Masyarakat" EDAJ3(1)(2014). Jurusan Ekonomi Pembangunan Universitas Negeri Semarang.

Rubin, Herbert dan Irene S. Rubin,.1992. Community Organizing and Development. Mac Milian Publishing Company, New York.

Sari, Ayuditya Widha Kurnia. 2013. Peran Kredit Usaha Rakyat (KUR) Bank Jateng Terhadap Perkembangan Usaha Mikro Di Kabupaten Boyolali. Skripsi. Fakultas Ekonomika dan Bisnis Universitas Diponegoro.

Sugiyono, (2016), Metode Penelitian Manajemen, Bandung, Alfabeta.

Suryana, Sawa. 2010. Pemberdayaan Masyarakat. Jakarta: Bumi Aksara

Suharto, Edi (2017), Membangun Masyarakat, Memberdayakan Rakyat: Kajian Strategis Pembangunan Kesejahteraan Sosial dan Pekerja Sosial, Bandung, PT Refika Aditama

Tambunan, Tulus,(2012) “Usaha Mikro Kecil dan Menengah di Indonesia : isu-isu penting”, Jakarta, LP3ES.

Undang-Undang Republik Indonesia Nomor 20 Tahun 2008 Tentang Usaha Mikro, Kecil, dan Menengah dan Undang-Undang Republik Indonesia.

Peraturan Menteri Koperasi dan Usaha Kecil dan Menengah Nomor 6 Tahun 2020. BN.2020/No.899, peraturan.go.id : $14 \mathrm{hlm}$ 